\section{A CRANE VISITOR}

On Saturday, October 12, a lone Sandhill Crane appeared in our garden some 30 yards from the house. It flew to the dugout, about 300 yards southwest, but returned walking. It flew over a shelterbelt and alighted in the pasture east of the house where my twin grandchildren and I followed it to get a closer look. To our great surprise is allowed us to "herd" it for a quarter of a mile, at times approaching to within 25 or 30 yards of it. It was not lame and could fly beautifully, which it did for a few yards when we crowded it.

It returned again Sunday flying to the dugout and walking back to the pasture.

Monday noon my wife heard it calling so we went out to investigate and found it circling high overhead. It drifted away to the southeast and I afterwards heard that it was seen by neighbours some three miles away. About 2:30 p.m. it came flying through the yard so I phoned my brother, a camera enthusiast. In the car we were able to get within 30 feet and were able to get several good shots of it.

The crane should be taking off for the south soon for it cannot survive the winter here and too many people would be only too glad to shoot it, but when it leaves we shall certainly miss it.

I missed it for a couple of days but it came into the yard this morning (Sunday, October 20). It shows no alarm but just does not want to be pressed. A moving picture camera would have done better justice to it, especially its take - off. It slowly "cranes" its neck then starts running, taking slow but tremendously long steps until it becomes air-borne.Guy C. Coates, Leask, Saskatchewan.

\section{UNUSUAL - UNUSUAL}

Unusual may be an odd form of title but the items I am about to relate are rather unusual under any circumstances.
On a Saturday in August this yea my wife and I went to visit one 0 : the old retired pioneer naturalists 0 : this magazine: Mrs. M. Hermansky and her brother, Mr. Theo Martinov sky, who live on the banks of the beautiful Cutarm creek just west 0 the town of Gerald. While walking through their garden we chanced to see an albino chipmunk, rather tame to say the least. There was only : very faint trace of fawn to indicate the chipmunk streaks. You can rest assured that the four of us had him cornered fairly close for observation but we had no camera.

On departure we ran into another unusual creature near our parked car a red-bellied snake Storeria occipito maculata occipitamaculata. F. R. Cook in the Museum's popular series No. 13 Amphibians and reptiles of Saskat. chewan, states that there is no other Saskatchewan snake that has a red underside, and that it is the smallest. This one was about eight inches long. The Resource Reader notes that it grows to about 10 inches. Unfortunately people are often prejudiced against snakes, and we had quite a time to protect this small inoffensive, defenceless little creature from destruction.-Anthony J. Hruska, Gerald, Sask.

\section{THE DEER MOUSE AS A NEST COMPETITOR AND POSSIBLE PREDATOR OF THE MOUNTAIN BLUEBIRD}

by Jon E. Swenson, Shepherd, Montana

As Power (1966:351) has stated, many observers believe that the Mountain Bluebird population is declining in much of its range. Although the following observations neither support nor refute this belief, they do suggest a phenomenon that may on occasion cause a temporary and localized decline in the bluebird population.

For two years records were kept on the Mountain Bluebirds nesting in 16 nest boxes erected in the ponderosa pine covered foothills of the Bull 
Mountains near Shepherd, approximately 23 miles WNW of Billings, Yellowstone County, Montana.

In 1968, the first possible case of predation by the Deer Mouse (Peromyscus maniculatus) was observed on the study area. Nest box 11 contained four newly hatched bluebirds and one infertile egg on May 31. The nest was empty on June 8 and contained five young Deer Mice when the nest was checked again on June 18. Nest box 3 contained five eggs on May 8 and 12 . On May 31 a nest was built over the original nest, which was empty. On June 8, five more eggs were found. Six eggs remained in the nest until July 2. A mouse nest was built in it between July 22 and September 15. This nest may have been abandoned before the mice arrived. The third case of suspected harassment which may have led to abandonment was found in box 2. A successful first brood of five young was fledged. Then later, four eggs were found on July 2. Two cold eggs were in the nest on July 22, one of which was broken. These eggs should have hatched before July 22, if the nest had not been abandoned. A mouse nest was also found in this box on September 15 .

Deer Mice have been suspected of usurping the active nests of other birds. Berger (1968) suspected them of destroying active nests of American Goldfinches. Deer Mice were suspected of eating three eggs and six young of Horned Larks in a study conducted by Verbeek (1967). Van Tyne and Berger (1959:282) state that Peromyscus spp. often reappropriate bird nests and it is likely that they eat the eggs in active nests before they remodel the nests.

In Power's (op. cit.) three year study of the Mountain Bluebird near Calvert, Montana, he found only one case of a Deer Mouse occupying a nest box. This box was unoccupied by bluebirds at the time. In 1966 in southwestern Manitoba, Deer Mice (rather than "White-footed Mice" as reported) were found using 12 bluebird nest boxes out of 1200 boxes that had been checked (Miller, 1966), but nothing was said regarding the relationship ketween the mice and bluebirds that may have used the boxes. Both Mountain and Eastern bluebirds were involved.

Seven (44 per cent) of the 16 nest boxes in my study contained mouse nests on September 15, although they were apparently appropriated after the young birds had fledged, with the possible exception of the three cases mentioned. Only one of the mouse nests was built in a box that had not been used by bluebirds. If Deer Mice were responsible for three nests being abandoned in this study, they could be classed as serious nest competitors in this area at least. A combination of a high Deer Mouse population and a shortage of suitable nesting sites for Mountain Bluebirds could certainly have a detrimental effect on the nesting success of the species, even if only for a limited time and in a localized area.

The Deer Mice were identified from a specimen taken from box 10 and from the sighting in box 11.

Miller's (1968) observations of predation on the Eastern Bluebird by an Eastern Chipmunk (Tamias striatus) prompted this report.

I am grateful to Don C. MacDonald and Helen Carlson for encouragement and for helping me with field observations, to Louis M. Moos for providing suggestions and invaluable assistance, and to Dr. Clifford V. Davis for suggestions and for critically reviewing the manuscript.

\section{LITERATURE CITED}

Berger, A. J. 1968. Clutch size, incubation period and nesting period of the American Goldfinch. Auk, 85 :494-498.

Miller, W. 1966. The annual report of the Brandon Junior Bird Club's nest project. Blue Jay, $24: 197-198$.

Miller, W. 1968. Predation of bluebirds by an Eastern Chipmunk. Blue Jay, $26: 145$.

Power, H. W. 1966. Biology of the Mountain Bluebird in Montana. Condor, 68:351-371.

Van Tyne, J., and A. J. Berger. 1959. Fundamentals of ornithology. John Wiley and Sons, Inc., New York, xi plus $624 \mathrm{pp}$.

Verbeek, N. A. M. 1967. Breeding biology and ecology of the Horned Lark in alpine tundra. Wilson Bulletin, $79: 208-218$. 